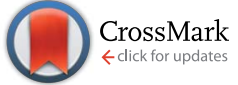

Cite this: RSC Adv., 2014, 4, 34356

\title{
Hybrid periodic mesoporous organosilica designed to improve the properties of immobilized enzymes $\uparrow$
}

\author{
V. Gascón, I. Díaz, R. M. Blanco and C. Márquez-Álvarez*
}

Two types of highly ordered periodic mesoporous organosilicas have been synthesized as tailor-made supports to immobilize two different enzymes, lipase and laccase. These materials provide an environment where abundant organic groups in close vicinity to the enzyme surface generate a high chemical affinity, which results in high values of enzyme loading, catalytic activity and stabilization. A hydrophobic periodic mesoporous organosilica support (PMO) with a highly ordered hexagonal arrangement of parallel pore channels with a diameter around $7 \mathrm{~nm}$, containing framework hydrocarbon groups (ethylene), was used for lipase immobilization. A novel periodic mesoporous aminosilica (PMA), containing secondary amine groups in its framework and having expanded pores was synthesized and studied for immobilization of a larger enzyme, namely laccase. The synthesis conditions were adjusted, using bis[(3-trimethoxysilyl)propyl]amine and 1,2-bis(trimethoxysilyl)ethane as framework co-precursors and 1,3,5-triisopropylbenzene as micelle expander for producing large pores (>10 nm). The properties of this multifunctional PMA having hydrophilic amino groups and hydrophobic ethylene/propylene groups within the framework were studied. This work compares the confinement of lipase and laccase enzymes in the pores of these hybrid organosilica materials and its effect on immobilization and stabilization parameters. Laccase immobilized on PMA and lipase immobilized on PMO exhibited higher stability in solvents (ethanol and methanol, respectively) compared to enzymes supported on functionalized silica materials with pending organic groups on the surface. High retention of enzymes inside the pores of these materials has been achieved and leaching has been fully prevented. These results can be attributed to the different interactions (hydrophobic, electrostatic and hydrogen bonding) established between the surfaces of the enzyme and the PMO/PMA support, which are enhanced by an optimum pore size

adjusted to the enzyme dimensions.

Received 5th June 2014

Accepted 30th July 2014

DOI: $10.1039 / c 4 r a 05362 a$

www.rsc.org/advances

\section{Introduction}

Siliceous ordered mesoporous materials (OMM) have burst into the field of enzyme immobilization as excellent supports to obtain nanostructured biocatalysts with improved properties. ${ }^{1}$ Three main parameters of these materials can be controlled by adjusting the synthesis conditions: (a) pore connectivity through a regular porous network, (b) pore size, which can be fine-tuned to accommodate the dimensions of the enzyme for optimal confinement, and (c) surface chemical functionalization to enhance enzyme-support affinity. This control enables one to obtain biocatalysts with improved properties regarding enzyme loading, catalytic efficiency, stability, and leaching prevention. ${ }^{2}$

The development of hybrid periodic organo-bridged silicas with ordered mesopores and large pore diameter is a breakthrough in the field of ordered mesoporous materials. In these

Molecular Sieves Group. Institute of Catalysis and Petroleum Chemistry (ICP-CSIC), C/ Marie Curie, 2. Cantoblanco 28049, Madrid, Spain. E-mail: cmarquez@icp.csic.es; Fax: +34915854760; Tel: +34915854785

$\dagger$ Electronic supplementary information (ESI) available. See DOI: 10.1039/c4ra05362a periodic mesoporous organosilicas (PMO), the organic groups are not anchored to the surface but become part of the framework. Using such hybrid supports allows one to avoid the pore size reduction that occurs upon grafting of the organic functionality on the surface of purely inorganic supports, which might hinder diffusion of enzyme molecules. ${ }^{3}$ However, literature regarding bulky enzyme immobilization on these materials is rather scarce.

The synthesis of PMO materials is carried out using bridged alkoxysilane molecules $\left(\left(\mathbf{R}^{\prime} \mathrm{O}\right)_{3} \mathrm{Si}-\mathbf{R}-\mathrm{Si}\left(\mathrm{OR}^{\prime}\right)_{3}\right.$; R: bridging hydrocarbon group, $\mathbf{R}^{\prime}$ : methyl or ethyl) as precursors. ${ }^{\mathbf{4}-6}$ New hybrid organic-inorganic OMM offer more possibilities for application, particularly in enzyme immobilization., ${ }^{4,7}$ The porous structures, surface, and framework properties of PMO materials can be finely tuned by changing the bridging organic groups incorporated and the synthesis conditions employed. ${ }^{9-13}$ However, the lack of structural rigidity of the organic moiety of the silsesquioxane may result in a disordered material, especially when attempting to synthesize materials with large pore size.

Initially, research on PMOs had been focused on the incorporation of small aliphatic moieties (methylene, ${ }^{14}$ ethylene, ${ }^{12,15}$ 
ethenylene ${ }^{\mathbf{1 6}}$ ) into the walls of the channel-like structures, obtaining different morphologies. ${ }^{17,18}$ Later, organic bridges in the framework were extended to more functional species ranging from hydrocarbons and heteroaromatics to metal complexes. Recent developments in novel PMO involve innovation in their components and structural designs. Multifunctional PMO can be easily obtained by co-condensation of a mixture of bridged organosilane precursors with different surface properties of the pore walls. ${ }^{19-23}$ For example, Morell et al., 2006 (ref. 24) incorporated aromatic bridging groups (phenylene and thiophene) and obtained PMO materials with pore sizes in the range of 4.8-5.4 nm employing the triblock copolymer Pluronic P123 as structure-directing agent.

The limited pore size of PMO materials may restrict their applications in some areas where large pores are essential for adsorption and immobilization of large biomolecules, ${ }^{25}$ and only a few works have been published regarding the immobilization of bulky enzymes, for which large pores are required. ${ }^{26,27}$ In comparison with their purely siliceous counterparts, pore size is more difficult to adjust in PMO. ${ }^{16,28}$

We have formerly described the immobilization of Candida antarctica lipase B ( $C a \mathrm{LB})$ on a PMO material containing ethylene groups. ${ }^{29}$ Lipases are known to have a hydrophobic domain, which often constitutes a lid responsible for their interfacial activation. ${ }^{30} \mathrm{CaLB}$ lacks this lid, ${ }^{31,32}$ but still has the hydrophobic domain on its surface. Supports with hydrophobic surfaces can interact with this domain to drive lipase immobilization, therefore, PMO containing ethylene bridges were obtained and tested as supports in our group.

Laccase is a larger enzyme than $C a \mathrm{LB}$, therefore two challenges are to be faced. One is the increase of chemical affinity and the other is obtaining a support with pore size large enough to accommodate the enzyme. We have recently reported ${ }^{33}$ the immobilization of laccase on OMM with expanded pore size functionalized with amine groups anchored on the silica surface. The large difference between the pI of laccase (around 4) and the $\mathrm{p} K_{\mathrm{a}}$ value of these groups (close to 10) enabled strong electrostatic interactions in a broad $\mathrm{pH}$ range. Based on these results we report here the synthesis of large-pore periodic mesoporous organosilica materials containing amino groups within the framework as supports for immobilization of laccase. Few attempts to introduce nitrogen-containing groups into the walls of hybrid organosilica materials have been reported. Asefa et al., 2003 (ref. 34) prepared periodic mesoporous aminosilica (PMA) materials that contained amine functional groups within the framework via thermal ammonolysis of PMOs under a flow of ammonia gas. The pore diameter of these materials was around 3-4 $\mathrm{nm}$. It has also been reported the synthesis of PMA using silane precursors with amine groups. However, it has to be noticed that the order of the structure is an issue. The increase in concentration of the bridged alkoxysilane with nonrigid organic bridges may lead to a decrease in the order of the material, as reported by Wahab et al., 2004 (ref. 4) even for materials with pore size as small as $3.5 \mathrm{~nm}$. An interesting transition of the mesostructure of this system was observed with increasing content of bis[(3-trimethoxysilyl)propyl]-amine (BTMSPA) in the starting mixture for the co-condensation of
BTMSPA and 1,2-bis(trimethoxysilyl)ethane (BTME) in the presence of octadecyltrimethylammonnium chloride. ${ }^{35}$ When the ratio of BTME-BTMSPA was changed from $90: 10$ to $55: 45$, a change from a $2 \mathrm{D}$ hexagonal $(p 6 \mathrm{~mm})$ to a cubic mesophase took place. Higher BTMSPA concentrations in the reaction mixture led to the collapse of the structure. Tan et al., 2006 (ref. 36) obtained uniform mesopores in a material made with BTMSPA using hexadecyltrimethylammonium bromide (CTAB) as template. When BTMSPA was used, the hydrophilic chain helped to promote co-assembly of the precursor with CTAB micelles, limiting bulk condensation. The reported material had relatively low pore volume and specific surface area, as well as a reduced pore diameter $(3.1 \mathrm{~nm})$ but it had a combination of uniform pore size and amine groups integrated in the pore walls. In all these reported works, the pore sizes obtained were always smaller than those attainable for pure silica and did not exceed $6 \mathrm{~nm}$. This factor limits the potential applications of PMAs as supports for the immobilization of large enzymes.

On the basis of previous works with laccase immobilized on OMM with SBA-15 structure and expanded pores, functionalized with primary amine groups anchored to the siliceous surface, we report here the synthesis of a novel hybrid material: periodic mesoporous aminosilica with large pore size. The aim of this work is to study and compare the behaviour of two model enzymes, laccase and lipase confined within the pores of two different periodic mesoporous organosilica supports.

\section{Experimental}

\section{Materials and Reagents}

Triblock copolymer $\mathrm{PEO}_{20} \mathrm{PPO}_{70} \mathrm{PEO}_{20}$ (Pluronic P123) and 1,2bis(trimethoxysilyl)ethane (BTME) were from Aldrich (USA). 3Aminopropyltriethoxysilane (APTES) and bis[3-(trimethoxysilyl)propyl]amine (BTMSPA) were purchased from TCI (Belgium). 1,3,5-Tiisopropylbenzene (TIPB) and n-octyltriethoxysilane (OTES) were from Alfa Aesar (Germany). Amorphous silica MS3030 was kindly donated by Silica PQ Corporation (USA).

The extracts of soluble laccase from Myceliophthora thermophila (Suberase) and lipase from Candida antarctica B (Lipozyme $C a \mathrm{LB} \cdot \mathrm{L})$ both expressed in Aspergillus oryzae were kindly donated by Novozymes (Denmark). 2'-Aino-bis-(3-ethylbenzothiazoline-6-sulfonic acid) diammonium salt (ABTS), $p$ nitrophenyl acetate ( $p$-NPA), tributyrin (TB), mercaptoethanol, bromophenol blue and glycerol were from Sigma (USA). Bovine serum albumin (BSA, Sigma-Aldrich, USA) was used as protein standard for protein content determination by the Bradford method. ${ }^{37}$ The reagents for electrophoresis SDS-PAGE (sodium dodecyl sulfate (SDS), ammonium persulfate, $N, N, N^{\prime}, N^{\prime}$-tetramethylethylenediamine (TEMED), $40 \%$ acrylamide/bis solution, $10 \times$ Tris base/glycine/SDS buffer and bio-safeTM coomasie G250 stain) and broad molecular weight standards were from BioRad (USA).

Citric acid, potassium chloride, phosphoric acid, sodium carbonate, sodium bicarbonate and toluene were purchased from Sigma-Aldrich (USA). Acetonitrile and sodium acetate were purchased from Scharlau (Spain). Sodium dihydrogen phosphate 1-hydrate, hydrochloric acid, ethanol, acetic acid, 
potassium dihydrogen phosphate, disodium hydrogen phosphate, sodium hydroxide, potassium phosphate and acetone were purchased from Panreac (Spain). Trisodium citrate dehydrate was from Analyticals Carlo Erba (Italy). Tris(hydroxymethyl)aminomethane (Tris base) was purchased from Fluka Analytical (USA). Solvents were all analytical or HPLC grade, salts were of high purity and water was Milli-Q grade. All materials were used as obtained without further purification.

\section{Synthesis of hybrid periodic mesoporous materials}

Ethylene-bridged periodic mesoporous organosilica (PMO) was synthesized as previously reported ${ }^{29,38}$ with few modifications. $3.19 \mathrm{~g}$ of Pluronic P123 were dissolved at room temperature in $126.84 \mathrm{~mL}$ of $0.174 \mathrm{M} \mathrm{HCl}$ aqueous solution in a flask with slow stirring. Once the surfactant was dissolved, $9.38 \mathrm{~g}$ of $\mathrm{KCl}$ were added. Both, the low acid concentration and the presence of inorganic salts play an important role in the formation of highly ordered materials. ${ }^{12,18,38-40}$ When the resulting solution was homogenized, it was heated in a thermostated water bath to a constant temperature of $40^{\circ} \mathrm{C}$. Then, $3.97 \mathrm{~mL}$ of bis-functional alkoxysilane, BTME, were added at once with rapid stirring. The resulting mixture was stirred at $40{ }^{\circ} \mathrm{C}$ for $24 \mathrm{~h}$ and then aged at $100{ }^{\circ} \mathrm{C}$ under static conditions for $24 \mathrm{~h}$. Subsequently, the solid product was recovered by filtration, washed with ethanol and dried at room temperature for $24 \mathrm{~h}$. The surfactant was removed from the material by two successive reflux extractions in ethanol/HCl (1.5 g of as-made PMO in a solution made with $20 \mathrm{~mL}$ of $35 \mathrm{wt} \% \mathrm{HCl}$ and $205 \mathrm{~mL}$ of ethanol) for $24 \mathrm{~h}$. The resulting solid was recovered by filtration, washed with ethanol, and dried in air.

\section{Aminodipropyl-bridged periodic mesoporous aminosilica (PMA)}

Materials synthesized using only the highly flexible aminodipropyl-bridged silane collapsed upon surfactant extraction due to the lack of structural rigidity of the framework. ${ }^{4,34}$ Therefore, in order to obtain well-ordered pore structures PMA materials were synthesized by co-condensation of ethylene- and aminodipropyl-bridged silanes.

For the standard synthesis of periodic mesoporous aminosilica (PMA), $3.19 \mathrm{~g}$ of P123 were dissolved in $126.8 \mathrm{~mL}$ of a 0.17 $\mathrm{M} \mathrm{HCl}$ aqueous solution. To this homogeneous mixture, $9.38 \mathrm{~g}$ $\mathrm{KCl}$ were added. The mixture was slowly stirred for $24 \mathrm{~h}$. Then, $3.49 \mathrm{~g}$ of 1,2-bis(trimethoxysilyl)ethane (BTME) and $0.95 \mathrm{~g}$ of bis(3-trimethoxysilyl)propylamine (BTMSPA) were added, and the solution was stirred at $40{ }^{\circ} \mathrm{C}$ for $24 \mathrm{~h}$. The mixture was aged at $100{ }^{\circ} \mathrm{C}$ under static conditions for $24 \mathrm{~h}$. The solution was filtered and the solid product was washed with ethanol and airdried at room temperature. The surfactant was extracted from the sample by two successive reflux extractions in ethanol/HCl, as indicated above for the PMO sample. The solution was filtered, and the solid product was washed with ethanol and dried under ambient conditions.

The synthesis of pore-expanded PMA (E-PMA) followed similar procedure with some modifications. $1.595 \mathrm{~mL}$ of the micelle expander agent TIPB were added to the surfactant solution and the mixture cooled down to $18^{\circ} \mathrm{C}$ prior to addition of BTME and BTMSPA. The suspension was kept under stirring at $18{ }^{\circ} \mathrm{C}$ for $24 \mathrm{~h}$. The obtained solid was suspended in $200 \mathrm{~mL}$ toluene and refluxed for 24 hours before being filtered and washed with ethanol. The solid was then submitted to reflux extraction in ethanol/HCl and dried in the same way as PMA.

\section{Functionalization of mesoporous materials by grafting}

For comparative purposes, commercial mesoporous amorphous silica (AS) was functionalized with both amine $e^{33}$ and hydrophobic groups ${ }^{41}$ to immobilize laccase and lipase, respectively.

The parent material $(1.1 \mathrm{~g})$ was degassed at $80{ }^{\circ} \mathrm{C}$ under vacuum for $18 \mathrm{~h}$ and then dispersed in a solution containing the organoalkoxysilane selected for the functionalization process (22 mmol of 3-aminopropyltriethoxysilane (APTES) or $29 \mathrm{mmol}$ of $n$-octyltriethoxysilane (OTES)) in $100 \mathrm{~mL}$ of toluene. The mixture was refluxed under $\mathrm{N}_{2}$ stream for $24 \mathrm{~h}$. The suspension was filtered, washed twice with dry toluene, three times with acetone and finally was dried at room temperature for $24 \mathrm{~h}$. These supports are named NAS (amine-functionalized amorphous silica) and OAS (octyl-functionalized amorphous silica).

\section{Characterization of supports}

Mesoscopic order was investigated by low-angle X-ray diffraction (XRD) using a PANalytical X'Pert diffractometer with $\mathrm{Cu} \mathrm{K}_{\alpha}$ radiation.

Nitrogen adsorption-desorption isotherms were measured at $-196{ }^{\circ} \mathrm{C}$ using two Micromeritics sorptometers (ASAP 2020 and ASAP 2420) to determine textural properties. Pure silicas were pretreated at $350{ }^{\circ} \mathrm{C}$ for $16 \mathrm{~h}$ and the functionalized supports, at $120^{\circ} \mathrm{C}$ for $16 \mathrm{~h}$. The specific surface area, $S_{\mathrm{BET}}$, was calculated from nitrogen adsorption data in the relative pressure range from 0.04 to 0.2 using the Brunauer-Emmet-Teller (BET) method. ${ }^{42}$ The total pore volume, $V_{\mathrm{p}}$, was determined from the amount adsorbed at a relative pressure $P / P_{\mathrm{o}}$ of $0.97 .{ }^{42}$ Pore size distributions were determined from the adsorption branch of the isotherms using the Barrett-Joyner-Halenda (BJH) model with cylindrical geometry of pores. The BJH pore diameter, $D_{\mathrm{p} \text { вJH }}$, is defined as the position of the maximum in the pore size distribution.

Quantitative determination of the nitrogen content of amino-functionalized supports (NAS, PMA and E-PMA) was performed using a LECO CHNS-932 Elemental Analyser with a Perkin Elmer AD-4 autobalance.

Thermogravimetric analyses of the supports were carried out using a Perkin Elmer TGA 7 instrument. Samples were heated under synthetic air flow $\left(60 \mathrm{~mL} \mathrm{~min}{ }^{-1}\right)$ from 25 to $900{ }^{\circ} \mathrm{C}$ at a rate of $20{ }^{\circ} \mathrm{C} \mathrm{min}^{-1}$.

Transmission electron micrographs (TEM) were taken using a JEOL 2100 electron microscope operating at $200 \mathrm{kV}$. The samples for TEM analysis were prepared by suspending a small amount of solid in acetone by sonication in an ultrasonic water bath for $10 \mathrm{~min}$. A drop of this suspension was then poured onto a copper grid coated with a holey carbon film and the solvent allowed to evaporate at room temperature. 


\section{Protein determination}

The crystal structure of Candida antarctica lipase B, CaLB (PDB: 1TCA $)^{44}$ was taken from the Protein Data Bank. ${ }^{45}$ CaLB has a molecular weight of $33 \mathrm{KDa}$ and an isoelectric point (pI) of 6.0. $C a \mathrm{LB}$ is a globular $\alpha / \beta$ type protein with approximate dimensions of $3 \mathrm{~nm} \times 4 \mathrm{~nm} \times 5 \mathrm{~nm}$.

Bioinformatic analysis was used to determine the aminoacid sequence and 3D structure of Myceliophthora thermophila laccase $(M t \mathrm{~L})$ because the crystal structure is not resolved. The amino acid sequence of MtL was taken from the NCBI Protein Database (accession number AEO 58496.1). ${ }^{46}$ This amino acid sequence was used as a template to identify homologous sequences of the laccase in BLASTP algorithm. ${ }^{47}$ The protein BLAST analysis for $M t \mathrm{~L}$ showed that it shares high identity (73\%) and query coverage (99\%) with the Melanocarpus albomyces laccase (PDB: 1GWO-A). ${ }^{45,48}$

The 3D structure of $M t \mathrm{~L}$ was modelled applying the alignment mode on the Swiss model server ${ }^{47,49-51}$ using the threedimensional structure of the Melanocarpus albomyces laccase. The modelled $M t \mathrm{~L}$ structure has been visualized using Pymol software. ${ }^{52}$ The molecular analysis of the whole protein using the tools ProtParam, ${ }^{53}$ UniProt KB (G2QFD0 and G2Q560) ${ }^{54}$ and Brenda $^{55}$ showed that it has a molecular weight between 63 and $80 \mathrm{KDa}$. The predicted isoelectric point (pI) was found to be 4.2. These data are in agreement with those reported by other authors. ${ }^{56,57} \mathrm{Mt} \mathrm{L}$ has approximate dimensions of $6.3 \mathrm{~nm} \times 7.2$ $\mathrm{nm} \times 8.9 \mathrm{~nm}$.

Protein content of solutions was determined with the BioRad Protein Assay (Bio-Rad, USA), based on the Bradford assay, ${ }^{37}$ using bovine serum albumin (BSA) as protein standard. The commercial extracts of laccase and lipase were found to contain a protein concentration of $3.3 \mathrm{mg} \mathrm{mL}^{-1}$ and $3.0 \mathrm{mg}$ $\mathrm{mL}^{-1}$, respectively.

SDS-polyacrylamide gel electrophoresis (SDS-PAGE) was performed for identification of the enzymes and determination of the purity of the commercial extracts. ${ }^{58}$

Proteins structural changes by organic solvents were evaluated spectrophotometrically by the changes in the UV-Vis spectra of enzyme solutions with different solvent concentration: laccase in $10 \%$ ethanol and $50 \mathrm{mM}$ sodium dihydrogenphosphate/disodium hydrogenphosphate buffer $\mathrm{pH}$ 7.0, and lipase in 50\% methanol and $50 \mathrm{mM}$ sodium dihydrogenphosphate/disodium hydrogenphosphate buffer $\mathrm{pH}$ 7.0 compared to the spectra registered by identical enzyme concentrations in their respective buffers.

\section{Enzymes immobilization}

Lipase immobilization was carried out according to a protocol previously reported. ${ }^{\mathbf{4 1 , 5 9 , 6 0}}$ Enzyme solutions of different concentrations were prepared in buffered solutions to carry out immobilization at selected $\mathrm{pH}$ values. The buffer solutions used and their corresponding $\mathrm{pH}$ were: $50 \mathrm{mM}$ glycine/hydrochloric acid ( $\mathrm{pH}$ 3.5), $50 \mathrm{mM}$ sodium acetate/acetic acid (pH 5.0), $50 \mathrm{mM}$ potassium dihydrogen phosphate/disodium hydrogen phosphate $(\mathrm{pH} 7.0)$ and $50 \mathrm{mM}$ sodium carbonate/sodium bicarbonate ( $\mathrm{pH}$ 9.0). To carry out the immobilization, $100 \mathrm{mg}$ of the support were impregnated with $0.5 \mathrm{~mL}$ ethanol (to facilitate its dispersion in aqueous solutions, due to the hydrophobic character of supports), and added to $10 \mathrm{~mL}$ enzyme solution. The suspension was kept under gentle stirring at room temperature. Aliquots of the suspension and supernatant were withdrawn at different times and assayed for catalytic activity measurement (pNPA test). The activity of a control enzyme solution was used as reference to evaluate the degree of enzyme immobilization with time. The time at which the residual activity of the supernatant reached a constant value was taken as the end of the immobilization process. The suspensions were then filtered, washed with $200 \mathrm{mM}$ of the respective buffer at the same $\mathrm{pH}$ as used for immobilization and subsequently with acetone and allowed to dry at room temperature. High concentration of buffers was preferred for washing in order to preserve hydrophobic interactions and thus preventing enzyme leaching in this step. Dried biocatalysts were stored at $4{ }^{\circ} \mathrm{C}$. Activity of the supported biocatalysts was determined by tributyrin hydrolysis assay. Suspensions with a lipase to support weight ratio between 20 and $600 \mathrm{mg} \mathrm{g}^{-1}$ were used to obtain adsorption isotherms (see Supplementary Information Fig. S1a $\dagger$ ) and determine the maximum enzyme loading capacity of the support under the best conditions of immobilization.

Laccase immobilization on the different supports was carried out at pH 5.5 (and also pH 6.0 for E-PMA) in $50 \mathrm{mM}$ acetic acid/ sodium acetate buffer solutions containing different enzyme concentrations. To the enzyme solution, $50 \mathrm{mg}$ of the support were added and kept in suspension under mild stirring at room temperature. Aliquots were withdrawn at given times and the enzymatic activities of suspension and supernatant were assayed (ABTS assay). The decrease of the supernatant activity to a minimum and constant value indicated the end point of the immobilization process. At this point, the solids were filtered off and washed with acetate buffer $(50 \mathrm{mM}$ at the same $\mathrm{pH}$ as used for immobilization). The solid samples were first dried under vacuum and then under nitrogen stream and stored at $4{ }^{\circ} \mathrm{C}$ for later analysis. Immobilizations were performed using different enzyme to support weight ratios in the range between 25 and $350 \mathrm{mg} \mathrm{g}^{-1}$ in order to determine adsorption isotherms and the maximum loading capacity for all supports (see Fig. S1b $\dagger$ for enzyme adsorption isotherms). To determine the catalytic activity of the supported biocatalysts, $10 \mathrm{mg}$ of the solid were suspended in $1 \mathrm{~mL}$ of $50 \mathrm{mM}$ acetate buffer (at the same $\mathrm{pH}$ as used for immobilization) and assayed in the ABTS oxidation test.

\section{Enzyme leaching study}

The resistance to enzyme leakage from the supports was studied under conditions that presumably favour the release of the protein, namely high dilution and low ionic strength. Lipase catalysts were suspended in $50 \mathrm{mM}$ potassium dihydrogen phosphate/disodium hydrogen phosphate at $\mathrm{pH}$ 7.0. The laccase catalysts were incubated in $50 \mathrm{mM}$ acetic acid/sodium acetate buffer at $\mathrm{pH}$ 4.5. Suspensions were prepared with $1.25 \mathrm{mg}$ of solid per $\mathrm{mL}$ of buffer solution and were incubated at $25{ }^{\circ} \mathrm{C}$. Enzyme leaching was calculated at different incubation times by 
measuring the amount of enzyme present in the supernatant using the Bradford assay. ${ }^{37}$ After the leaching treatment, the solids were separated by filtration, suspended in electrophoresis sample buffer (containing SDS, mercaptoethanol, bromophenol blue, Tris buffer pH 6.8 and glycerol) and boiled for $5 \mathrm{~min}$. After this treatment, proteins trapped in the solids would be denatured and the lineal polypeptide chains should be easily released from the pores. The supernatants of these suspensions were withdrawn and analysed by SDS-PAGE electrophoresis.

\section{Enzyme activity assays}

Routine laccase activity tests were carried out spectrophotometrically by measuring the increase in absorbance at $405 \mathrm{~nm}$ caused by the oxidation of ABTS. ${ }^{43}$ The reaction mixture consisted of a $1.6 \mathrm{mM}$ ABTS solution in $100 \mathrm{mM}$ acetic acid/sodium acetate buffer at $\mathrm{pH}$ 4.5. To $1.9 \mathrm{~mL}$ of this solution in the cuvette, $50 \mu \mathrm{L}$ of enzyme solution or suspension were added under stirring and the reaction was monitored continuously at $25{ }^{\circ} \mathrm{C}$ for $30 \mathrm{~min}$. One unit of laccase activity $\left(U_{\mathrm{ABTS}}\right)$ was defined as the amount of enzyme required to oxidize $1 \mu \mathrm{mol}$ of ABTS per minute at $25{ }^{\circ} \mathrm{C}$ (the molar absorption coefficient of oxidized ABTS at $405 \mathrm{~nm}$ was taken as $\varepsilon_{405} \mathrm{~nm}=35000 \mathrm{M}^{-1} \mathrm{~cm}^{-1}$ ).

In order to perform enzyme spectrophotometric assays at different $\mathrm{pH}$ values, the isosbestic point of oxidized ABTS (ABTS*) was determined and established at $430 \mathrm{~nm}$, and the molar absorption coefficient of ABTS* was calculated $\left(\varepsilon_{430 \mathrm{~nm}}=\right.$ $\left.20700 \mathrm{M}^{-1} \mathrm{~cm}^{-1}\right)$. The activities of the free and immobilized laccases (on PMA and NAS) were determined at this wavelength as a function of $\mathrm{pH}$, in $50 \mathrm{mM}$ phosphoric acid/sodium dihydrogenphosphate $(\mathrm{pH} 2.5)$ and $50 \mathrm{mM}$ citric acid/trisodium citrate (pH 3.0 to 6.0) buffer solutions at $25{ }^{\circ} \mathrm{C}$ (triplicated).

Hydrolysis of $p$-NPA was used as a routine test to measure the nonspecific esterase activity for monitoring the immobilization of lipase. An aliquot of $50 \mu \mathrm{L}$ of enzyme solution (control or supernatant) or immobilized enzyme suspension was added to a cuvette with $1.9 \mathrm{~mL}$ of $0.4 \mathrm{mM} p$-NPA aqueous solution ( $\mathrm{pH}$ 7.0). The activity was determined at $25^{\circ} \mathrm{C}$ by measuring the rate of increase of absorbance at $348 \mathrm{~nm}$ due to the release of $p$-nitrophenol (the molar absorption coefficient was taken as $\left.\varepsilon_{348 \mathrm{~nm}}=5150 \mathrm{M}^{-1} \mathrm{~cm}^{-1}\right)$.

Spectrophotometric assays of free enzyme and immobilized enzyme suspensions were performed using an Agilent 8453 UV-Vis spectrophotometer equipped with a stirring device and temperature control.

Lipase biocatalysts stability tests were performed using the hydrolysis of tributyrin as test reaction to evaluate hydrolytic activity of lipase. The activity was determined by titration of the butyric acid released by the hydrolysis of tributyrin. $1.47 \mathrm{~mL}$ of tributyrin were added under stirring to $48.5 \mathrm{~mL}$ of $10 \mathrm{mM}$ potassium phosphate buffer at $\mathrm{pH} 7.0$ in a thermostated titration vessel at $25{ }^{\circ} \mathrm{C}$. Once equilibrated at $\mathrm{pH}$ 7.0, a weighted amount of biocatalyst was added, and the rate of addition of a $0.1 \mathrm{M} \mathrm{NaOH}$ solution required to neutralize the acid product and maintain a constant $\mathrm{pH}$ of 7.0 was measured. One unit of activity $\left(U_{\mathrm{TB}}\right)$ was defined as the amount of lipase converting $1 \mu \mathrm{mol}$ of tributyrin per minute.
Titrimetric determination of lipase activity was performed using a Mettler Toledo DL-50 pH-state.

\section{Stability tests}

The thermal stability of free and immobilized enzymes was determined by incubation at $55{ }^{\circ} \mathrm{C}$ in $50 \mathrm{mM}$ potassium dihydrogen phosphate/disodium hydrogen phosphate buffer at $\mathrm{pH}$ 7.0 (for lipase) and at $60{ }^{\circ} \mathrm{C}$ in $50 \mathrm{mM}$ acetic acid/sodium acetate buffer at pH 5.5 (for laccase).

Stability of free and immobilized enzymes in organic solvents was evaluated by incubating samples at $25{ }^{\circ} \mathrm{C}$ in $50 \%$ $\mathrm{v} / \mathrm{v}$ methanol/water and pure methanol (lipase samples) or $10 \%$ $\mathrm{v} / \mathrm{v}$ ethanol at $\mathrm{pH} 3.5$ (laccase samples).

Incubations were performed in different vials for each aliquot to prevent solvent evaporation during sampling. Aliquots were withdrawn at different times, cooled down and their activities were assayed in the hydrolysis of tributyrin (lipase) or in the oxidation of ABTS (laccase).

\section{Results}

\section{Characterization of the supports}

TEM images of solvent-extracted hybrid organosilicas (Fig. 1) show large domains with two-dimensional hexagonal arrangements of parallel channels of uniform size. This is consistent with X-ray diffraction (XRD) patterns (see Supplementary Information Fig. S2 $\dagger$ ), which exhibit an intense reflection and two relatively well resolved weak peaks in the low angle region $\left(0.5-2^{\circ}\right)$, that can be indexed as the 100,110 and 200 reflections of p6mm hexagonal symmetry. These patterns indicate that the samples possess high degree of mesostructural order. In contrast with the hybrid organosilica supports, the XRD pattern of the commercial amorphous silica (not shown) does not exhibit any diffraction peak at low angle, evidencing the lack of mesoscopic order and, hence, the non-uniform pore structure of this material.

Fig. 2a shows nitrogen adsorption-desorption isotherms and the corresponding pore size distributions calculated by the $\mathrm{BJH}$ method for the solvent-extracted hybrid aminosilica samples. The isotherms are type IV, with $\mathrm{H} 1$ type hysteresis loop at high relative pressure, which is characteristic of mesoporous materials. The calculated pore size distributions (Fig. 2a, inset) indicate that the three samples possess uniform mesopores, in agreement with the regular pore structure shown by XRD and TEM.

The diameter of pore channels estimated by the BJH method is reported in Table 1. The pore size estimated for PMO and PMA supports is around $7 \mathrm{~nm}$. This value increases up to more than $10 \mathrm{~nm}$ when the synthesis of hybrid aminosilica was carried out using the swelling agent (sample E-PMA). In the case of sample E-PMA the nitrogen isotherm (Fig. 2a) shows that, besides the main steep nitrogen uptake at a relative pressure around 0.8 , corresponding to the regular mesopore channels, an additional increase of nitrogen adsorption occurs at relative pressures above 0.9. This is also apparent in the pore size distribution (Fig. 2a, inset) that evidences the presence of 

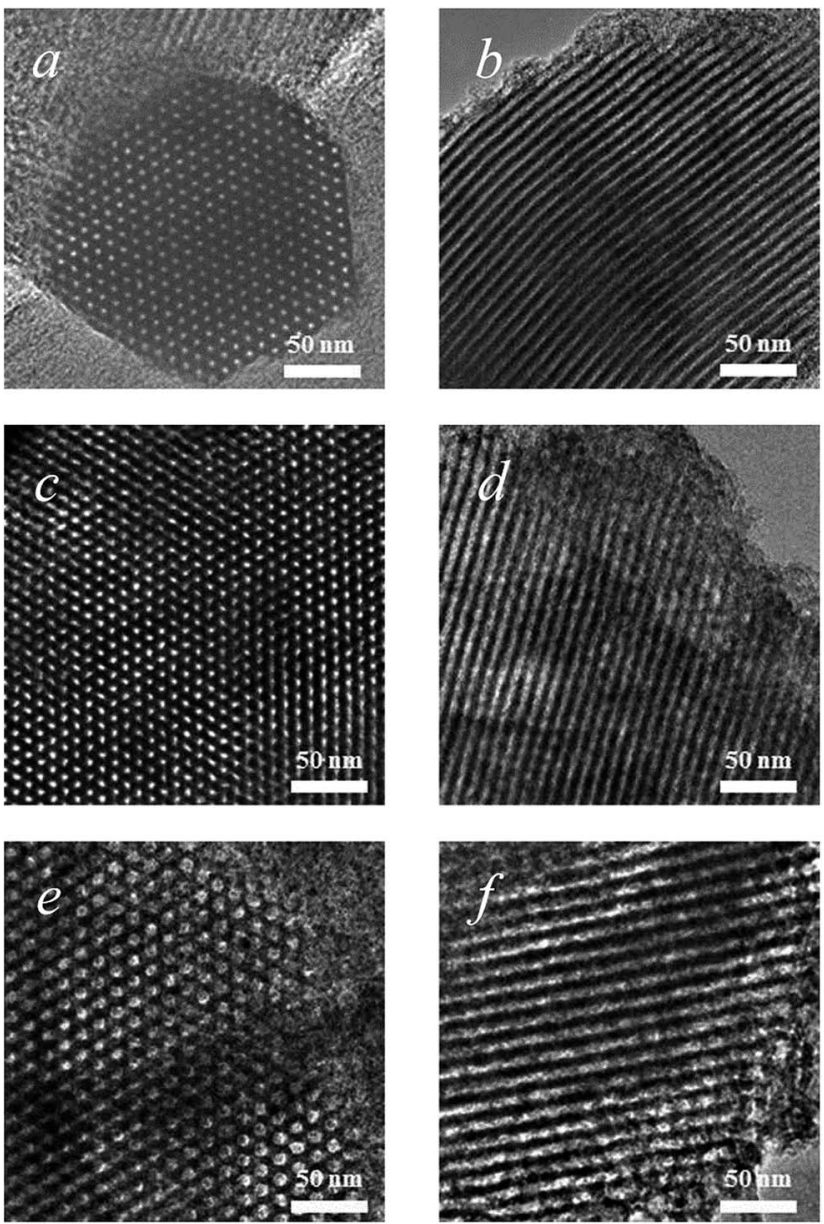

Fig. 1 TEM micrographs of PMO ( $a$ and b), PMA (c and d) and E-PMA (e and f).

secondary mesoporosity, with a relatively broad pore size distribution ranging from 15 to $30 \mathrm{~nm}$, which can be attributed to interparticle spaces. The three samples possess high surface area and pore volume (Table 1), although these parameters differ significantly among the three samples. Taking into account the unit cell parameters $\left(a_{0}\right)$ calculated from the XRD patterns (11.6, 12.4 and 15.9 for PMO, PMA and E-PMA, respectively) and the diameter of the pore channels determined from the nitrogen isotherms (Table 1), it can be estimated that the pore wall thickness of PMO, PMA and E-PMA is 4.5, 5.2 and $5.5 \mathrm{~nm}$, respectively. Therefore, the differences in textural properties might be attributed to the different pore size and pore wall thickness of the three samples.

Fig. 2b shows the $\mathrm{N}_{2}$ adsorption-desorption isotherms of the parent (AS) and functionalized amorphous silica supports (OAS and NAS). These supports show type IV isotherms corresponding to mesoporous materials..$^{29,41}$ In contrast with hybrid organosilicas, the commercial amorphous silica has a wide pore size distribution, indicating heterogeneity in the porous structure, and larger pores, with the maximum of the pore size distribution around $30 \mathrm{~nm}$ (Fig. 2b, inset). Functionalization of the AS support has a negligible effect on pore size (Fig. 2b, inset and Table 1), as can be expected due to the large pore size.
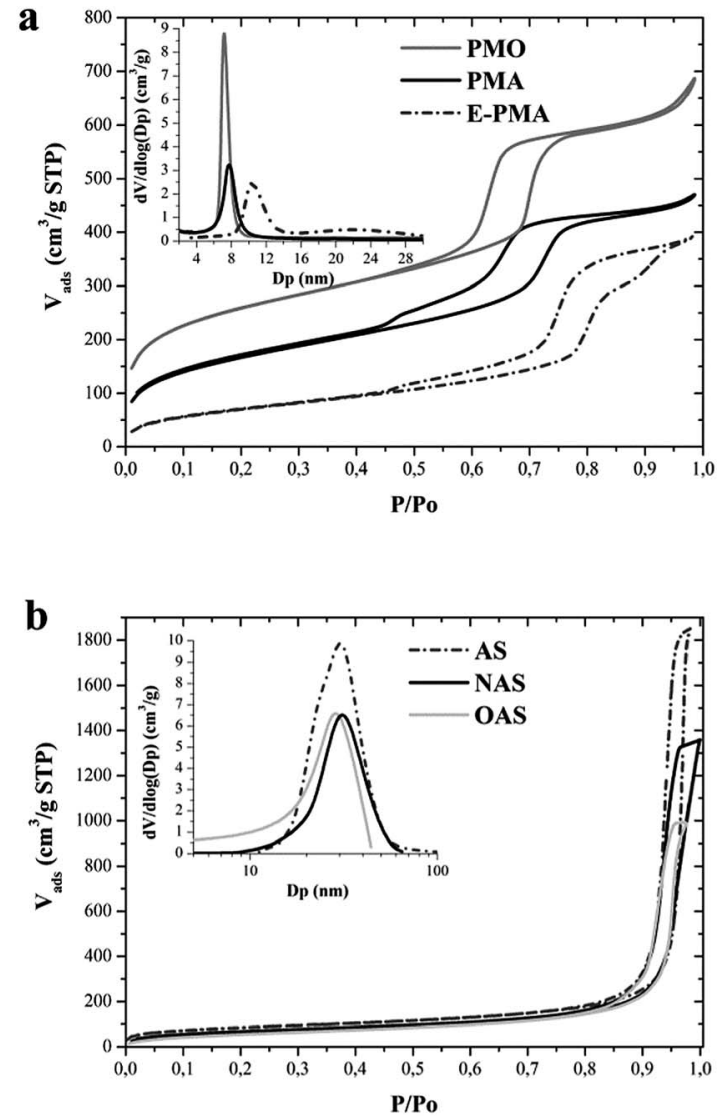

Fig. 2 Nitrogen adsorption isotherms and pore size distributions of: (a) hybrid organosilica supports and (b) parent and functionalized amorphous silica supports.

Nevertheless, grafting with aminopropyl or octyl groups on the silica surface produces a small decrease of both surface area and pore volume (Table 1 ).

Thermogravimetric analysis (TGA) profiles show the incorporation of organic groups in functionalized silica and hybrid organosilica supports (Fig. S3†). All materials show a small weight loss at temperatures below $150{ }^{\circ} \mathrm{C}$ that can be attributed to desorption of water or residual organic solvents. The main weight loss occurs in the temperature range $150-600{ }^{\circ} \mathrm{C}$, which corresponds to decomposition and combustion of the organic groups. At temperatures higher than $600{ }^{\circ} \mathrm{C}$ a further small weight loss is observed that that might be attributed to dehydroxylation of the silica surface. Therefore, the amount of hydrophobic groups (octyl chains in sample OAS and ethylene bridges in sample PMO) have been calculated from the weight loss in the temperature range $150-600{ }^{\circ} \mathrm{C}$. The results, expressed as mmol $\mathrm{C}$ per gram of silica are given in Table 1 . It can be seen that the total amount of carbon of the hybrid organosilica material is around four times that of the amorphous silica functionalized with octyl groups. In the case of supports containing amino groups (PMA and E-PMA), the weight loss assigned to removal of organic groups corresponds to both aminodipropyl and ethylene bridges. Therefore, the concentration of amino groups was determined by chemical analysis. All the supports obtained contain a relatively high 
Table 1 Textural properties and organic groups content of supports

\begin{tabular}{llllll}
\hline Material & $D_{\mathrm{p} \mathrm{BJH}}{ }^{a}(\mathrm{~nm})$ & $S_{\mathrm{BET}}{ }^{b}\left(\mathrm{~m}^{2} \mathrm{~g}^{-1}\right)$ & $V_{\mathrm{p}}^{c}\left(\mathrm{~cm}^{3} \mathrm{~g}^{-1}\right)$ & $\mathrm{mmol} \mathrm{C} \mathrm{g}^{-1} \mathrm{SiO}_{2}{ }^{d}$ & $\mathrm{mmol} \mathrm{N} \mathrm{g}^{-1} \mathrm{SiO}_{2}{ }^{e}$ \\
\hline AS & 30 & 285 & 2.2 & - & - \\
OAS & 30 & 212 & 1.6 & -2 & - \\
NAS & 30 & 236 & 2.1 & 16.1 & 1.8 \\
PMO & 7.1 & 882 & 1.0 & - & - \\
PMA & 7.2 & 594 & 0.7 & - & 1.5 \\
E-PMA & 10.4 & 264 & 0.6 &
\end{tabular}

${ }^{a}$ BJH pore diameter (nm). ${ }^{b}$ BET surface area $\left(\mathrm{m}^{2} \mathrm{~g}^{-1}\right) \cdot{ }^{c}$ Total pore volume $\left(\mathrm{cm}^{3} \mathrm{~g}^{-1}\right) \cdot{ }^{d}$ Hydrophobic (aliphatic carbon) groups content determined from TG analysis (weight loss in the temperature range $150-600{ }^{\circ} \mathrm{C}$ ). ${ }^{e}$ Concentration of amine groups determined by chemical analysis.

amount of amine, ranging from 1 to $1.8 \mathrm{mmol}$ per gram of silica (Table 1).

\section{Lipase immobilization on PMO at different $\mathrm{pH}$ values}

The loading capacity of PMO for lipase immobilization was determined at $\mathrm{pH} 5.0$ by the adsorption isotherm at room temperature (ESI, Fig. S1†). Maximum enzyme loading remained nearly constant (about $90 \mathrm{mg}$ enzyme per gram of support) at a content of enzyme in the liquid phase over $100 \mathrm{mg}$ $\mathrm{g}^{-1}$. This can be attributed to the relatively small pore size that would prevent multilayer adsorption of enzyme. In contrast, on the octyl-functionalized amorphous silica support OAS, lipase loadings up to $400 \mathrm{mg}$ enzyme per gram of support were obtained $^{29}$ due to its larger pore size. However, this high enzyme loading leads to lower catalytic efficiency (90 $U_{\mathrm{TB}}$ per mg of enzyme, compared to $200 U_{\mathrm{TB}} / \mathrm{mg}$ for the PMO-supported catalyst $^{29}$ ). This is probably due to the intense interaction with the highly hydrophobic octyl groups. Despite each single interaction is mild, the high content in ethylene groups and the high contact surface in PMO due to the confinement of enzyme within the pore, makes the overall interaction intense. But the mild interactions permit the catalyst to preserve high catalytic activity. ${ }^{29}$

Suspensions with $90 \mathrm{mg}$ enzyme per gram of support were prepared to evaluate the effect of $\mathrm{pH}$ on lipase immobilization on PMO. The maximum amount of lipase slightly decreased as the $\mathrm{pH}$ increased from 3.5 to 9.0 (Table 2). In the whole $\mathrm{pH}$ range used for lipase immobilization, silanol groups present on the support should be deprotonated, as the point of zero charge (pzc) of silica is around 2. Taking into account that the isoelectric point (pI) of lipase is around 6.0, electrostatic attractions or repulsions may also be established with the remaining siloxane groups on the surface of $\mathrm{PMO}^{22}$ when the immobilization is performed at $\mathrm{pH} 3.5-5.0$ or $\mathrm{pH} 7.0-9.0$ respectively. Although maximal loading was achieved at $\mathrm{pH} 3.5$ and 5.0, as expected, the values are rather close indicating that the driving forces of the immobilization are hydrophobic interactions.

\section{Laccase immobilization on PMA}

The low isoelectric point of laccase (4.2) permits a wide $\mathrm{pH}$ range for electrostatic interactions between negatively charged enzyme and positively charged amine groups of the hybrid aminosilica supports ( $\mathrm{p} K_{\mathrm{a}}$ around 11.0). Thus, immobilization was tested at $\mathrm{pH}$ 5.5. Because of the similar size between the dimensions of laccase $(6.3 \times 7.2 \times 8.9)$ and the pore diameter of PMA (7.2 nm), maximal loading in this support is low, as well as activity and efficiency of the biocatalyst (Table 3 ). The enzyme molecules are probably absorbed only onto the external surface of PMA particles.

Loading capacity of our expanded pore material E-PMA with $10.2 \mathrm{~nm}$ pore diameter was tested. Table 3 shows the loading capacities of the three amine-coated supports. The rise in pore size enabled a twofold increase in the enzyme loading of E-PMA compared to PMA. Also, amine-functionalized amorphous silica was tested for comparative purposes. Similarly to lipase immobilization, the highest laccase loading was achieved in amorphous silica with much larger pore size. However, it is worth noting that adsorption equilibrium was reached more rapidly for the supports with uniform pore size.

It was also observed that increasing the $\mathrm{pH}$ of laccase solution to 6.0 led to a faster adsorption and higher enzyme loading on E-PMA: $119 \mathrm{mg} \mathrm{g}^{-1}$ vs. $88.0 \mathrm{mg} \mathrm{g}^{-1}$ at $\mathrm{pH}$ 5.5. However the catalytic efficiency was significantly decreased at $\mathrm{pH} 6.0$.

Table 2 Immobilization of lipase on PMO at different $\mathrm{pH}$ values from suspensions containing 90 mg lipase per gram of support

\begin{tabular}{|c|c|c|c|c|}
\hline $\mathrm{pH}$ & $t_{\mathrm{c}}^{a}(\mathrm{~h})$ & $\operatorname{Max} . \operatorname{load}^{b}\left(\mathrm{mg} \mathrm{g}^{-1}\right)$ & Biocatalyst activity $^{c}\left(U_{\mathrm{TB}} / \mathrm{g}\right)$ & Cat. eff. ${ }^{d}\left(U_{\mathrm{TB}} / \mathrm{mg}\right)$ \\
\hline 3.5 & 1.25 & 77.05 & 2377.8 & 30.9 \\
\hline 5 & 1.25 & 70.18 & 4020 & 57.3 \\
\hline 9 & 1.75 & 49.14 & 1952.4 & 39.7 \\
\hline
\end{tabular}

${ }^{a}$ Time at which the maximum loading is achieved. ${ }^{b}$ Maximum enzymatic loading, expressed in milligrams of lipase per gram of support.

${ }^{c}$ Biocatalyst activity expressed in $U_{\text {Тв }}$ per $g$ of support. ${ }^{d}$ Catalytic efficiency expressed in $U_{\text {тв }}$ per mg of lipase. 
Table 3 Immobilization of laccase on different supports

\begin{tabular}{lccccc}
\hline Support & $\mathrm{pH}^{a}$ & $t_{\mathrm{c}}^{b}(\mathrm{~h})$ & ${\text { Max. } \operatorname{load}^{c}\left(\mathrm{mg} \mathrm{g}^{-1}\right)}^{\text {Biocatalyst activity }^{d}\left(U_{\mathrm{ABTS}} / \mathrm{g}\right)}$ & Cat. eff. $^{e}\left(U_{\mathrm{ABTS}} / \mathrm{mg}^{\prime}\right)$ \\
\hline NAS & 5.5 & 24 & 187 & 170 & 0.91 \\
PMA & 5.5 & 2.0 & 42 & 4.7 & 0.11 \\
E-PMA & 5.5 & 1.5 & 119 & 29 & 0.33 \\
E-PMA & 6.0 & 1.3 & 19 & 0.16
\end{tabular}

${ }^{a} \mathrm{pH}$ of immobilization. ${ }^{b}$ Time at which the maximum loading is achieved. ${ }^{c}$ Maximum enzymatic loading, expressed in milligrams of laccase per gram of supported biocatalyst. ${ }^{d}$ Biocatalyst activity expressed in $U_{\mathrm{ABTS}}$ per g. ${ }^{e}$ Catalytic efficiency expressed in $U_{\mathrm{ABTs}}$ per mg of lipase.

Fig. 3 shows the $\mathrm{pH} /$ activity profiles of laccase in soluble and immobilized estates. It can be observed that for laccase supported on NAS, the optimum $\mathrm{pH}$ was 0.5 units higher than that of soluble laccase. This result might be explained assuming that amino groups incorporated into materials generate a new environment which may result in a $\mathrm{pH}$ gradient from inside the particle towards the external aqueous medium in which catalyst particles are suspended. This trend had been previously found with expanded-pore SBA-15 materials functionalized with primary amine groups, where optimum $\mathrm{pH}$ was shifted $0.5 \mathrm{pH}$ units, as well as NAS. ${ }^{33}$ The shift of optimum $\mathrm{pH}$ underwent by laccase immobilized on E-PMA was much more pronounced: from $\mathrm{pH} 3.0$ to $\mathrm{pH}$ 5.0. As noted, laccase immobilized in the supports showed higher activity than the free enzyme in the $\mathrm{pH}$ range 4.0-6.0. This effect can be attributed to the microenviromental conditions ${ }^{61}$ in this material, with secondary amines in the close vicinity of enzyme.

\section{Leaching and electrophoresis}

In former works we had determined the amount of lipase leached from OAS and PMO after two hour incubation under conditions of charge repulsion and high dilution, where the release of the enzyme is favoured and expected. ${ }^{29} \mathrm{We}$ present here a $24 \mathrm{~h}$ time course of enzyme leaching (Fig. 4a). Lipase in PMO only undergoes a $15 \%$ initial leaching that may be due to removal of enzyme molecules immobilized on the outer surface of PMO particles, and then no more leaching was detected. Leaching of lipase from OAS is higher and growing with incubation time.

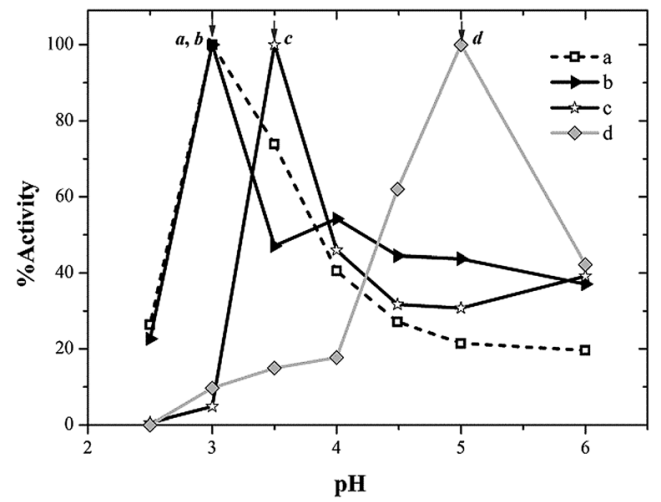

Fig. 3 Effect of pH on the activity of (a) free enzyme, (b) AS, (c) NAS and (d) E-PMA.
Lipase tightly fitting into pores of PMO and fixed by ethylene groups is highly retained. In contrast, stronger interaction with octyl groups of OAS does not prevent enzyme from leaching through the $30 \mathrm{~nm}$ with pores of amorphous silica. These results seem to suggest that it both, chemical affinity and confinement in the pore contribute to minimize enzyme leaching.

The same trend is observed for laccase leaching from catalysts (Fig. 4b). NAS catalyst shows a continuous release of enzyme. Again, the affinity of laccase with amine groups is not enough to prevent leaching from pores with an average diameter of around $30 \mathrm{~nm}$, with no diffusion restrictions. As shown
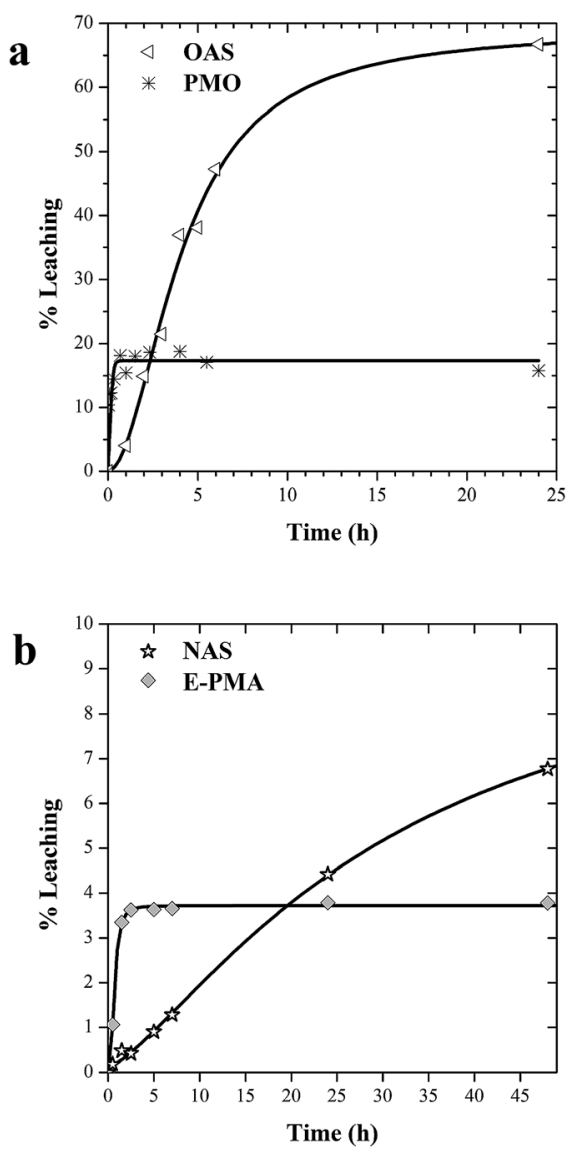

Fig. 4 (a) Leaching of lipase from ordered material (PMO) and amorphous mesoporous silica (OAS). (b) Leaching of laccase from ordered material (E-PMA) and amine amorphous silica (NAS). Expressed as percent of the initial enzyme leached on each material as a function of time. 
in Fig. 4b, leaching profile in E-PMA showed also initial desorption, probably due to enzyme molecules immobilized on external surfaces. But percent values of laccase leached are much lower than in the case of lipase (4\%). The uniform pore size close to the enzyme dimensions along with the increased affinity of the laccase for secondary amine groups make this material more efficient to retain the enzyme inside the inner surfaces.

An attempt to verify the location of enzymes inside the porous network of the materials was made. Since solid samples of the biocatalysts are not suitable for electrophoresis, the enzymes were forced to exit the pores. First, biocatalysts were suspended as described above for leaching tests to desorb as much enzyme as possible, especially to eliminate all protein molecules adsorbed on the external surface of support particles. Then the supernatants were removed and the filtered solids were boiled in sample electrophoresis buffer. In such denaturing conditions including the split of disulphide bonds, the tertiary structure of the protein should be lost and the random coil chain should then be easily released from the pores. However, no protein band could be seen from the E-PMA supernatant electrophoresis (Fig. S4a $\dagger$ ). Then, E-PMA samples after the same SDS-PAGE treatment were centrifuged and suspended at pH 11 and 14 respectively and the supernatants were analysed again. Protein band only appeared in the supernatant of the sample suspended at $\mathrm{pH}$ 14.0. These results confirm the presence of the enzyme inside the pores, in agreement with previous results based on advanced TEM techniques ${ }^{62}$ and evidence the strong binding of the enzyme to the inner surface of the support.

The results obtained with lipase catalysts are shown in Fig. S4c. $\dagger$ In this case no further incubation was necessary, and the band corresponding to the immobilized lipase appeared from both, PMO and OAS.

\section{Thermal stability}

The thermal stability of enzymes catalysts is important for some industrial applications ${ }^{63}$ because bioreactors are sometimes operated at elevated temperatures to improve productivity and to avoid microbial contamination.

Free and immobilized lipases were incubated in buffer at 55 ${ }^{\circ} \mathrm{C}$ and their inactivation courses are shown in Fig. 5. Lipase on PMO was inactivated at a faster rate than free enzyme, while maximal stabilization was achieved in OAS.

Thermal stabilities of free and immobilized laccase on NAS and E-PMA materials were evaluated at $60{ }^{\circ} \mathrm{C}$ in the same way. Again, a faster inactivation rate was underwent by laccase in $\mathrm{E}$ PMA and immobilization in NAS resulted in enzyme stabilization (Fig. 6).

\section{Stability in organic solvents}

Lipase can be used in the synthesis of biodiesel to catalyse both, the hydrolysis of triacylglycerols to release fatty acids and the methanolysis of these fatty acids. ${ }^{64-67}$ The biocatalytic pathway is attractive due to the easier purification of products and environmental advantages. ${ }^{\mathbf{8 , 6 8}}$ However, the necessary presence

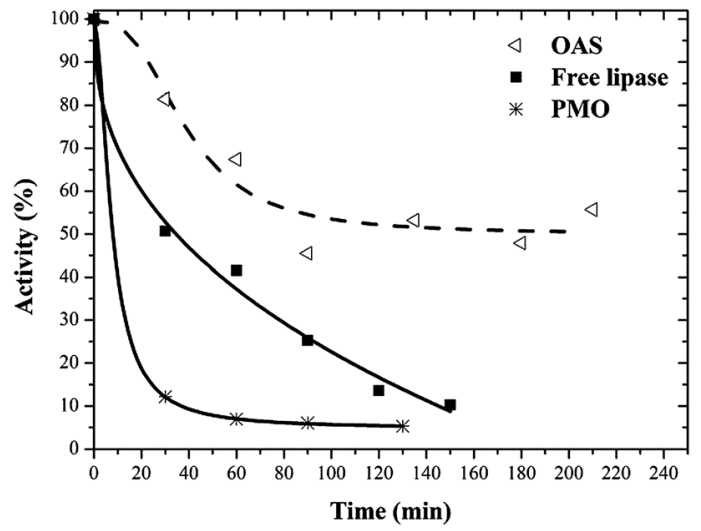

Fig. 5 Thermostability profiles at $55^{\circ} \mathrm{C}$ of free and immobilized lipase on PMO and octyl amorphous silica (OAS).

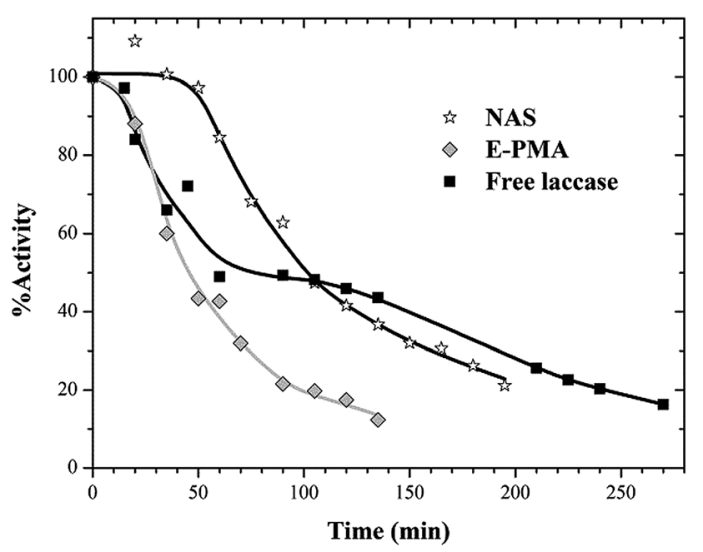

Fig. 6 Thermostability profiles at $60^{\circ} \mathrm{C}$ of free and immobilized laccase. Runs were performed at $\mathrm{pH} 5.5$.

of methanol involves severe losses of enzymatic activity because of structural and inhibitory damages on the enzyme. ${ }^{66,69}$ This solvent was chosen to study the structural protection that PMO may provide.

PMO-lipase incubated in 50\% methanol remained fully active after 24 hours, although the stability of the soluble enzyme was also high, as well as the one on OAS (Fig. 7a). Severe effects on the activity were registered by incubation in $100 \%$ methanol, where soluble lipase and OAS-lipase kept only $25 \%$ and $32 \%$ residual activity after 1 hour respectively. In the same conditions PMO-lipase still kept 75\% activity (Fig. 7b). But the activity was almost completely lost at longer incubation time for the three samples, probably because of inhibitory effect of methanol.

Laccase has been used to partially oxidize wine polyphenols. $^{\text {70-72 }}$ Therefore, in order to evaluate the potential application of PMA-laccase biocatalysts in wine stabilization, the stability of biocatalysts was tested by incubation in a low ethanol concentration. Free laccase, NAS and E-PMA were incubated in a medium similar to wine: $10 \%$ ethanol and acidic pH (Fig. 8). Inactivation was faster in the native enzyme, while NAS preserved around $85 \%$ activity after 6 hours incubation and 

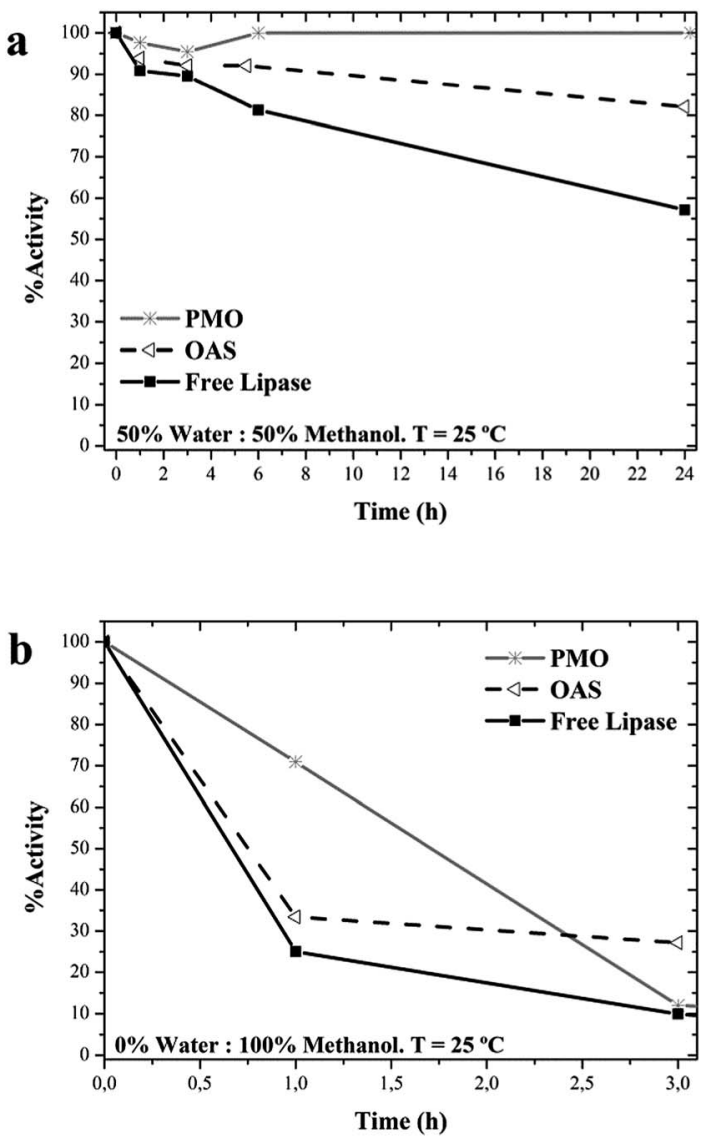

Fig. 7 Stability of lipase in solution and supported on OAS and PMO in: (a) $50 \%$ aqueous solution: $50 \%$ methanol; (b) $0 \%$ aqueous solution: $100 \%$ methanol. Runs were performed at $25^{\circ} \mathrm{C}$.

laccase immobilized on PMA remained fully active during the same period of time.

Fig. 9 shows the UV-Vis spectra of soluble enzymes: lipase in buffer and 50\% methanol (a) and laccase in buffer and 10\% ethanol (b). Proteins absorbance at $280 \mathrm{~nm}$ is due to the presence of aromatic side chain of aminoacids, especially tryptophan. Spectra of the enzyme in the presence of cosolvents show

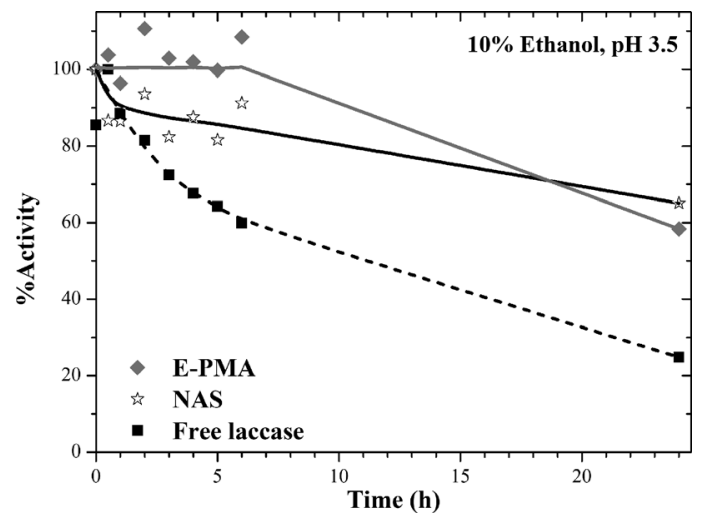

Fig. 8 Stability of free and immobilized laccase in ethanol : water solution at acidic $\mathrm{pH}$. Runs were performed at $25^{\circ} \mathrm{C}$.
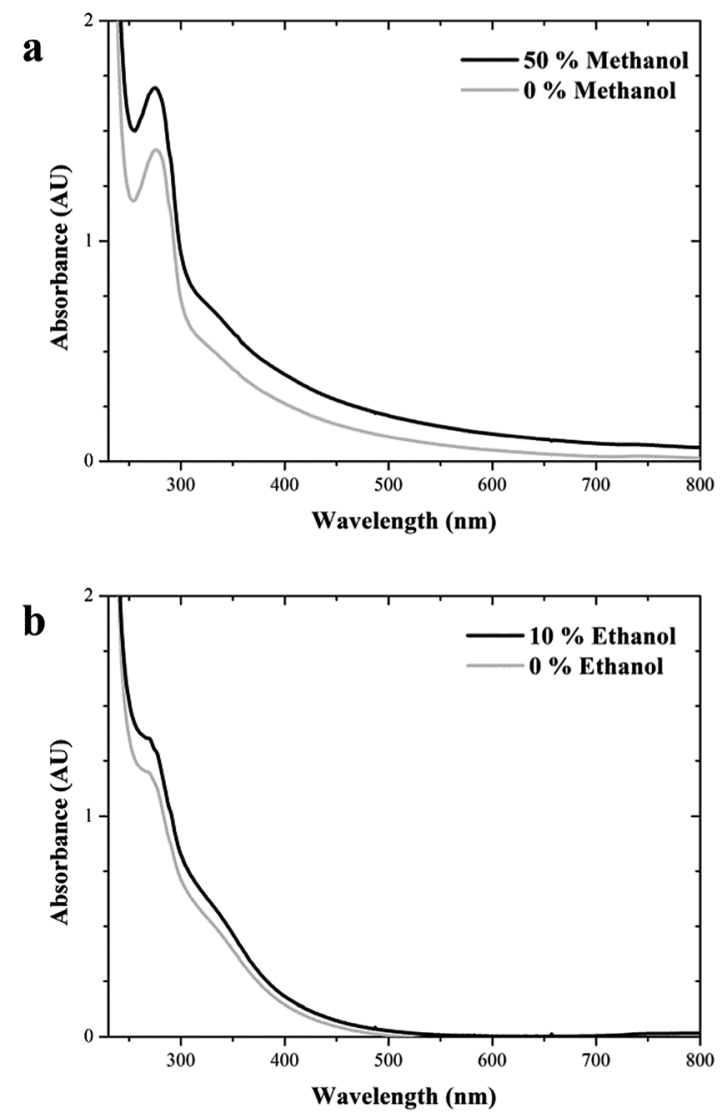

Fig. 9 UV-Vis spectra of lipase in aqueous buffer and $50 \%$ methanol (a) and laccase in aqueous buffer and $10 \%$ ethanol (b).

higher peaks of absorbance at $280 \mathrm{~nm}$, which suggests a higher amount of these aromatic aminoacids on the surface of the protein.

\section{Discussion}

The main characteristics of periodic mesoporous organosilica as support for enzyme immobilization are the confinement and the presence of chemical functionalities. These chemical groups are not anchored on the internal surface of pores but become part of it. These two features mean that there is close vicinity between the side chain groups of the enzyme and the functional groups of the support with no steric hindrances. Apart from the specific organic moieties introduced in the synthesis of the PMO (ethylene bridges) and PMA (dipropylamine and also ethylene bridges), silanol groups are present on the surface of silica that can also play their part.

The same loading of lipase on PMO was achieved at pH 5.0 and 7.0 despite repulsion should be established at the higher $\mathrm{pH}$ between negative charges on both, enzyme and support. What this probably means is that hydrophobic interactions are the driving forces of the process, over electrostatic ones. The only difference is found in the contact time: immobilization is faster at $\mathrm{pH} 5.0$ than at $\mathrm{pH}$ 7.0. Also, the highest values of catalytic efficiency were found at $\mathrm{pH} 5.0$ and 7.0. At $\mathrm{pH} 3.5$ 
higher loading was achieved as a result of the additional electrostatic attraction (the enzyme should have a net positive charge while the support is negatively charged). Nevertheless, the catalytic efficiency was lower probably because an excessive interaction is established with a distortional effect on the protein structure.

The immobilization of laccase showed higher values of enzyme loading and catalytic efficiency on the amorphous and wide pore support NAS. Although this amine-functionalized amorphous silica has lower surface area than E-PMA, the available surface in E-PMA is much lower because only one molecule of enzyme occupies the whole pore section, as the pore size is close to enzyme dimensions. Thus, the maximal capacity for enzyme immobilization determined for NAS was around four times higher than on E-PMA (Table 3). The intensity of the interaction with laccase is not identical for both supports since there are primary propylamine groups $\left(\mathrm{p} K_{\mathrm{a}}\right.$ around 10) in NAS and secondary dipropylamine groups in E-PMA ( $\mathrm{p} K_{\mathrm{a}}$ around 11). The interaction of negative charges of enzyme with these high $\mathrm{p} K_{\mathrm{a}}$ should be more intense and this is probably the reason why the catalytic efficiency is lower. As discussed for lipase-PMO, the stronger interaction may distort protein structure. This may also explain that immobilization at pH 6.0 displays higher enzyme loading and lower catalytic efficiency than at $\mathrm{pH} 5.0$, because of the higher density of negative charges on the enzyme.

This high $\mathrm{p} K_{\mathrm{a}}$ in E-PMA is also responsible for a higher density of positive charges at the same $\mathrm{pH}$, and consequently a higher $\mathrm{pH}$ gradient between the inner pores of the particles and the external medium. As a consequence, there is a large optimum $\mathrm{pH}$ shifting in the activity $v s$. $\mathrm{pH}$ profile, and it is likely that the immobilization inside the particle is occurring at a lower $\mathrm{pH}$ than measured in the bulk of the solution.

The absence of enzyme leaching from E-PMA samples can also be explained by this property. The protein unfolded under denaturing conditions does not leave the pores at $\mathrm{pH}$ below 11, probably because electrostatic attractions remain even in the random coil configuration. Only at $\mathrm{pH}$ extremely high ( $\mathrm{pH} 14.0)$ all amino groups from support should be deprotonated and repulsive forces would be driving the release of protein from pore channels. These experiments reveal that leaching only occurs in very harsh conditions, showing that this non-covalent immobilization is nearly as irreversible as a covalent one.

Unfolding of the protein is promoted by both, high temperature and organic solvents. These conformational changes may drive the formation of new interactions of side chain amino acids with the support, but the processes do not occur identically.

At high temperature the close vicinity of amines (or ethylenes) and silanol groups promotes abundant new interactions with amino acids exposed upon partial unfolding of the peptide chain. In our experiments, incubation of the catalysts suspensions or enzyme solutions were performed at high temperatures, and cooled down to the assay temperature $\left(25^{\circ} \mathrm{C}\right.$ for lipase and laccase). The fact that in both cases: PMO-lipase and E-PMAlaccase resulted the least stable ones may be related to confinement. Probably the interactions established between the enzyme structure, partially unfolded upon heating and the "close-fitting-around" support, are preserved after cooling. Thus, refolding to a more active conformation is prevented and the activity would be irreversibly lost in PMO/E-PMA biocatalysts. Neither enzymes in the wide-pore amorphous silica (OAS, NAS) nor the free enzymes have this restriction from the support, and this absence of steric hindrance would still permit some margin for reversibility. As a consequence the enzymes can partially recover their native conformation at lower temperatures.

Only the lipases naturally contain a hydrophobic domain on their surface. With this exception, hydrophobic side chains of aminoacids are usually placed inside the protein globule, avoiding contact with aqueous medium. Cosolvents miscible in water are known to interfere hydrogen bonds and to unfold proteins, thus forcing some hydrophobic amino acids to arise to the external surface. Spectra in aqueous and organic media of both lipase and laccase (Fig. 9) show a moderate higher absorbance at $280 \mathrm{~nm}$ in the organic solvents, which is usually attributed to tryptophan residues (hydrophobic) and confirm this effect of the solvents on both enzymes. PMO and E-PMA surfaces are contain ethylene bridges capable to establish new interactions with these arising hydrophobic groups. The stabilization results confirm that PMO and E-PMA are highly efficient to stabilize lipase and laccase versus methanol and ethanol respectively (Fig. 7 and 8). This higher presence of hydrophobic aminoacids on the external protein surface increases the bonding intensity with the close support surface containing ethylene groups. In the case of E-PMA-laccase, new hydrophobic interactions are added to the former electrostatic ones.

Aminoacids involved in unfolding promoted by high temperature and solvents are different, thus the new interactions and the structure of the partially unfolded proteins are also different. If the change does not lead to inactive conformations (as it happens by heating) the result is the stabilization of an active conformation, which becomes strengthened by abundant non-covalent bonds with the support.

The close match of sizes of enzyme and pore channels is the key to obtain this stabilization since the tertiary structure of the protein is physically prevented to keep on unfolding. However, laccase immobilized on ordered mesoporous materials (OMM) with similar structure and pore size bearing aminopropyl groups anchored on the surface had proven less stable than laccase-EPMA catalyst in the same conditions. ${ }^{33}$ The difference between both kinds of materials is that the organic moiety becomes part of the wall of the channel pores in the PMO/E-PMA materials, at the same level as silanols. Aminoacids can easily interact with either the negatively charged siloxanes or the ethylene bridges or dipropylamine groups. It is noticeable that in the case of E-PMA interactions can be established with the three of them. In the OMM materials where organic moieties are anchored to the siliceous surfaces, the silanol groups of the wall are not as accessible, as they are partially hindered by the propylamine or alkyl chains. Thus, additional interactions are not easily established.

\section{Conclusions}

We have synthetized a novel periodic mesoporous aminosilica with a pore size that matches with the dimensions of the 
enzyme laccase. The effects of presence of ethylene bridges and dipropylamine groups becoming part of the surface on laccase immobilization and the behaviour of the catalyst have been studied and compared to lipase immobilized on an ethylenebridged PMO. The PMO materials display some specific properties which enable the immobilization with high enzyme loading while retaining high catalytic activity and providing protection against inactivation in organic solvents. This is possible because these materials integrate organic and inorganic components in a restricted space where the interaction with the enzyme takes place all around the enzyme molecules and the mobility is prevented. Interactions are also feasible with silanol (or siloxane) groups which are not hindered by organic groups since these are also part of the support framework. Moreover, the number of contact points increase in the presence of an organic cosolvent, where additional hydrophobic interactions are established. The highly ordered structure contributes to keep high catalytic efficiency because it favours pore connectivity.

Laccase undergoes an especially strong interaction with secondary amines of E-PMA, which fully prevents leaching at $\mathrm{pH}$ below 14 . This is a relevant result since the non-covalent nature of the linkage permits to recover the support after enzyme inactivation, namely by suspending it at elevated $\mathrm{pH}$. Lipase immobilization on ethylene-bridged periodic mesoporous organosilica (PMO) appeared to be the most promising approach, since it occurred with high efficiency, maintained enzyme activity, and provided enzyme stability.

\section{Acknowledgements}

Authors thank the Spanish MINECO for the financial support through the project MAT 2012-31127. We thank D. Ramiro Martinez (Novozymes, Spain) for his kind help with the supply of enzymes. V. G. acknowledges Ministerio de Educación, Cultura y Deporte for a FPU PhD fellowship (AP2010-2145).

\section{Notes and references}

1 M. Hartmann and D. Jung, J. Mater. Chem., 2010, 20, 844.

2 M. Hartmann and X. Kostrov, Chem. Soc. Rev., 2013, 42, 6277-6289.

3 E. Serra, A. Mayoral, Y. Sakamoto, R. M. Blanco and I. Diaz, Microporous Mesoporous Mater., 2008, 114, 201-213.

4 M. A. Wahab, I. Kim and C. S. Ha, J. Solid State Chem., 2004, 177, 3439-3447.

5 N. Mizoshita, T. Tani and S. Inagaki, Chem. Soc. Rev., 2011, 40, 789-800.

6 K. Ariga, A. Vinu, Y. Yamauchi, Q. Ji and J. P. Hill, Bull. Chem. Soc. Jpn., 2012, 85, 1-32.

7 W. J. Hunks and G. A. Ozin, J. Mater. Chem., 2005, 15, 37163724 .

8 Z. Zhou and M. Hartmann, Chem. Soc. Rev., 2013, 42, 38943912.

9 T. Asefa, M. J. MacLachlan, N. Coombs and G. A. Ozin, Nature, 1999, 402, 867-871.
10 S. Inagaki, S. Guan, Y. Fukushima, T. Ohsuna and O. Terasaki, J. Am. Chem. Soc., 1999, 121, 9611-9614.

11 B. J. Melde, B. T. Holland, C. F. Blanford and A. Stein, Chem. Mater., 1999, 11, 3302-3308.

12 W. P. Guo, J. Y. Park, M. O. Oh, H. W. Jeong, W. J. Cho, I. Kim and C. S. Ha, Chem. Mater., 2003, 15, 2295-2298.

13 P. Van der Voort, D. Esquivel, E. De Canck, F. Goethals, I. Van Driessche and F. J. Romero-Salguero, Chem. Soc. Rev., 2013, 42, 3913-3955.

14 X. Y. Bao, X. Li and X. S. Zhao, J. Phys. Chem. B, 2006, 110, 2656-2661.

15 R. M. Grudzien, B. E. Grabicka and M. Jaroniec, Colloids Surf., A, 2007, 300, 235-244.

16 M. Mandal and M. Kruk, J. Mater. Chem., 2010, 20, 75067516.

17 C. H. Lee, S. S. Park, S. J. Choe and D. H. Park, Microporous Mesoporous Mater., 2001, 46, 257-264.

18 X. Y. Bao, X. S. Zhao, X. Li, P. A. Chia and J. Li, J. Phys. Chem. $B, 2004,108,4684-4689$.

19 O. Olkhovyk and M. Jaroniec, Ind. Eng. Chem. Res., 2007, 46, 1745-1751.

20 W.-H. Zhang, X. Zhang, L. Zhang, F. Schroeder, P. Harish, S. Hermes, J. Shi and R. A. Fischer, J. Mater. Chem., 2007, 17, 4320-4326.

21 E.-B. Cho, D. Kim and M. Jaroniec, Langmuir, 2009, 25, 13258-13263.

22 F. Goethals, B. Meeus, A. Verberckmoes, P. Van Der Voort and I. Van Driessche, J. Mater. Chem., 2010, 20, 1709-1716.

23 L. Xia, Y. Hu, Y. Wu, M. Zhang and M. Rong, J. Sol-Gel Sci. Technol., 2012, 64, 718-727.

24 J. Morell, M. Gungerich, G. Wolter, J. Jiao, M. Hunger, P. J. Klar and M. Froba, J. Mater. Chem., 2006, 16, 2809-2818.

25 X. Zhou, S. Qiao, N. Hao, X. Wang, C. Yu, L. Wang, D. Zhao and G. Q. Lu, Chem. Mater., 2007, 19, 1870-1876.

26 S. Z. Qiao, H. Djojoputro, Q. Hu and G. Q. Lu, Prog. Solid State Chem., 2006, 34, 249-256.

27 Z. Zhou, R. N. Klupp Taylor, S. Kullmann, H. Bao and M. Hartmann, Adv. Mater., 2011, 23, 2627-2632.

28 M. Mandal, A. S. Manchanda, J. Zhuang and M. Kruk, Langmuir, 2012, 28, 8737-8745.

29 E. Serra, E. Diez, I. Diaz and R. M. Blanco, Microporous Mesoporous Mater., 2010, 132, 487-493.

30 S. Rehm, P. Trodler and J. Pleiss, Protein Sci., 2010, 19, 21222130.

31 M. Martinelle, M. Holmquist and K. Hult, Biochim. Biophys. Acta, Lipids Lipid Metab., 1995, 1258, 272-276.

32 P. Trodler and J. Pleiss, BMC Struct. Biol., 2008, 8, 9.

33 V. Gascón, C. Márquez-Álvarez and R. M. Blanco, Appl. Catal., A, 2014, 482, 116-126.

34 T. Asefa, M. Kruk, N. Coombs, H. Grondey, M. J. MacLachlan, M. Jaroniec and G. A. Ozin, J. Am. Chem. Soc., 2003, 125, 11662-11673.

35 F. Hoffmann, M. Cornelius, J. Morell and M. Froba, J. Nanosci. Nanotechnol., 2006, 6, 265-288.

36 B. Tan and S. E. Rankin, J. Non-Cryst. Solids, 2006, 352, 54535462.

37 M. M. Bradford, Anal. Biochem., 1976, 72, 248-254. 
38 S. Z. Qiao, C. Z. Yu, Q. H. Hu, Y. G. Jin, X. F. Zhou, X. S. Zhao and G. Q. Lu, Microporous Mesoporous Mater., 2006, 91, 59-69.

39 X. Y. Bao, X. S. Zhao, S. Z. Qiao and S. K. Bhatia, J. Phys. Chem. B, 2004, 108, 16441-16450.

40 S. Urrego, E. Serra, V. Alfredsson, R. M. Blanco and I. Díaz, Microporous Mesoporous Mater., 2010, 129, 173-178.

41 R. M. Blanco, P. Terreros, M. Fernandez-Perez, C. Otero and G. Diaz-Gonzalez, J. Mol. Catal. B: Enzym., 2004, 30, 83-93.

42 K. S. W. Sing, Pure Appl. Chem., 1985, 57, 603-619.

43 O. V. Morozova, G. P. Shumakovich, S. V. Shleev and Y. I. Yaropolov, Appl. Biochem. Microbiol., 2007, 43, 523-535.

44 J. Uppenberg, M. T. Hansen, S. Patkar and T. A. Jones, Structure, 1994, 2, 293-308.

45 Rutgers and UCSD, RCSB Protein Data Bank, http:// www.rcsb.org/pdb/home/home.do, accessed 14 January 2014.

46 NCBI Protein Database, http://www.ncbi.nlm.nih.gov/ protein, accessed 14 January 2014.

47 Standard Protein BLAST, http://swissmodel.expasy.org/? pid $=$ smd05, accessed 14 January 2014.

48 N. Hakulinen, L. L. Kiiskinen, K. Kruus, M. Saloheimo, A. Koivula and J. Rouvinen, Nat. Struct. Biol., 2002, 9, 601-605.

49 K. Arnold, L. Bordoli, J. Kopp and T. Schwede, Bioinformatics, 2006, 22, 195-201.

50 L. Bordoli, F. Kiefer, K. Arnold, P. Benkert, J. Battey and T. Schwede, Nat. Protoc., 2009, 4, 1-13.

51 F. Kiefer, K. Arnold, M. Kunzli, L. Bordoli and T. Schwede, Nucleic Acids Res., 2009, 37, 387-392.

52 W. L. DeLano, The PyMOL Molecular Graphics System, http://www.pymol.org/, accessed 14 January 2014.

53 ExPASy - ProtParamtool, http://web.expasy.org/protparam/, accessed 14 January 2014.

54 UniProt KB, http://www.uniprot.org/uniprot/G2QFD0, accessed 14 January 2014.

55 B. T. C. E. I. System., http://www.brenda-enzymes.org/php/ result_flat.php4?ecno=1.10.3.2, accessed 14 January 2014.

56 R. M. Berka, P. Schneider, E. J. Golightly, S. H. Brown, M. Madden, K. M. Brown, T. Halkier, K. Mondorf and F. Xu, Appl. Environ. Microbiol., 1997, 63, 3151-3157.
57 R. M. Berka, I. V. Grigoriev, R. Otillar, A. Salamov, J. Grimwood, I. Reid, N. Ishmael, T. John, C. Darmond, M. C. Moisan, B. Henrissat, P. M. Coutinho, V. Lombard, D. O. Natvig, E. Lindquist, J. Schmutz, S. Lucas, P. Harris, J. Powlowski, A. Bellemare, D. Taylor, G. Butler, R. P. de Vries, I. E. Allijn, J. van den Brink, S. Ushinsky, R. Storms, A. J. Powell, I. T. Paulsen, L. D. Elbourne, S. E. Baker, J. Magnuson, S. Laboissiere, A. J. Clutterbuck, D. Martinez, M. Wogulis, A. L. de Leon, M. W. Rey and A. Tsang, Nat. Biotechnol., 2011, 29, 922-929.

58 U. K. Laemmli, Nature, 1970, 227, 680-685.

59 R. M. Blanco, P. Terreros, N. Munoz and E. Serra, J. Mol. Catal. B: Enzym., 2007, 47, 13-20.

60 E. Serra, V. Alfredsson, R. M. Blanco and I. Diaz, in Zeolites and Related Materials: Trends, Targets and Challenges, Proceedings of the 4th International Feza Conference, ed. A. Gedeon, P. Massiani and F. Babonneau, 2008, pp. 369-372. 61 M. Hartmann, Chem. Mater., 2005, 17, 4577-4593.

62 A. Mayoral, R. Arenal, V. Gascon, C. Marquez-Alvarez, R. M. Blanco and I. Diaz, ChemCatChem, 2013, 5, 903-909.

63 A. S. Bommarius and M. F. Paye, Chem. Soc. Rev., 2013, 42, 6534-6565.

64 K. Nie, F. Xie, F. Wang and T. Tan, J. Mol. Catal. B: Enzym., 2006, 43, 142-147.

65 C.-H. Kuo, L.-T. Peng, S.-C. Kan, Y.-C. Liu and C.-J. Shieh, Bioresour. Technol., 2013, 145, 229-232.

66 D. T. Tran, Y. J. Lin, C. L. Chen and J. S. Chang, Bioresour. Technol., 2013, 145, 193-203.

67 P. Adlercreutz, Chem. Soc. Rev., 2013, 42, 6406-6436.

68 B. D. Ribeiro, A. M. de Castro, M. A. Coelho and D. M. Freire, Enzyme Res., 2011, 2011, 615803.

69 C. Jose, G. B. Austic, R. D. Bonetto, R. M. Burton and L. E. Briand, Catal. Today, 2013, 213, 73-80.

70 R. C. Minussi, G. M. Pastore and N. Duran, Trends Food Sci. Technol., 2002, 13, 205-216.

71 A. Kunamneni, F. J. Plou, A. Ballesteros and M. Alcalde, Recent Pat. Biotechnol., 2008, 2, 10-24.

72 J. F. Osma, J. L. Toca-Herrera and S. Rodriguez-Couto, Enzyme Res., 2010, 2010, 918761. 